This is the author's final version of the work, as accepted for publication following peer review but without the publisher's layout or pagination.

The definitive version is available at

https://doi.org/10.1016/j.jclepro.2019.118694

\title{
Explaining the political nature of Environmental Impact Assessment (EIA): a neo-Gramscian perspective
}

Alan Bond* - School of Environmental Sciences, University of East Anglia; Research Unit for Environmental Sciences and Management, North-West University, South Africa

Co-authors: Jenny Pope - Integral Sustainability, Australia; Research Unit for Environmental Sciences and Management, North-West University, South Africa

Monica Fundingsland - Sustainability Department, Equinor ASA, Norway

Angus Morrison-Saunders - School of Science, Edith Cowan University, Western Australia; Research Unit for Environmental Sciences and Management, North-West University, South Africa

Francois Retief - Research Unit for Environmental Sciences and Management, North-West University, South Africa

Morgan Hauptfleisch - Department of Agriculture and Natural Resources Sciences, Namibia University of Science and Technology, Namibia

*corresponding author 


\begin{abstract}
Environmental Impact Assessment (EIA) is a mandatory decision-support tool in every country of the world, developed 50 years ago to ensure the consideration of the environmental consequences of development decisions prior to approval decisions being made. Specifically, the aim of developing an EIA system was to make decision-making affecting the environment more accountable, through the use of objective scientific evidence. It remains the project decision-support tool of choice despite considerable research efforts failing to provide convincing evidence that it achieves this aim. Here we explain this apparent paradox by arguing that EIA supports neoliberal agendas by facilitating economic development. We present arguments based on a neo-Gramscian perspective that explains how apparent advances in the practice of EIA are sanctioned because they actually maintain the political nature of the EIA system, which continues to undermine attempts to use evidence objectively. We use a narratives of change approach to support this perspective. We conclude that EIA can only make decision-making more accountable if strategies to depoliticise it are employed, including emphasising substantive outcomes.
\end{abstract}

\title{
Keywords
}

Hegemony; Legitimacy; Sustainability; Environmental Impact Assessment (EIA); Politics; Neoliberalism

\section{Introduction}

Environmental Impact Assessment (EIA) is defined as "the process of identifying, predicting, evaluating and mitigating the biophysical, social, and other relevant effects of development proposals prior to major decisions being taken and commitments made" (International Association for Impact Assessment and Institute of Environmental Assessment, 1999). It is a universally-applied tool that was developed to facilitate objective, evidence-based decision-making and to deliver greater accountability (Cashmore et al., 2010). Cashmore et al. (2010) further argue that the ascendency of impact assessment processes has led to increased interest in evaluating their effectiveness. That is, given the universal application of EIA, people want to know that it works. We follow Cashmore et al. (2010) in distinguishing between epistemic uncertainties and conceptual uncertainties that are associated with evaluations of effectiveness. The former relates to uncertainties over the attainment of goals of the EIA process; the latter relates to uncertainty over 
the meaning or intention of the goals. Here we argue that any action which perpetuates conceptual uncertainty related to EIA effectiveness has the effect of politicising EIA, undermining its ability to steer objective decision-making. Politicisation in the context of EIA means providing opportunities for different stakeholders to interpret the goals of IA as they see fit. This is important because politicised EIA, in which goals are ambiguous, can assist powerful actors to influence decisions to suit their own ends, whilst still being able to argue that EIA has been effective, thereby legitimising the decision. That is, conceptual uncertainty undermines the accountable use of scientific evidence as being determinative in decision-making.

A lack of agreed and unambiguous goals raises the potential for EIA to be manipulated to favour certain outcomes. On this basis, we argue that it is no coincidence that the timescale over which EIA has been the legislator's decision-support tool of choice is concurrent with the neoliberal hegemony. We define neoliberalisation after Brenner et al. (2010, p.184) as denoting "a politically guided intensification of market rule and commodification". In terms of timing Peck (2010, p.5) reports that "accounts of neoliberalism as a hegemonic wave tend, for understandable reasons, to begin in the $1970 s^{\prime \prime}$ and this accords with the emergence and spread of EIA. This was the point in time when a move from Keynesian economics to neoliberalism took place, with President Ronald Reagan in the US and Prime Minister Margaret Thatcher in the UK being at the vanguard of the pursuit of free market economies that emerged from a global recession (Jones, 2012). Quite simply, neoliberalism allows for the maximisation of profits in competitive markets. Both the neoliberal hegemony and the worldwide application of EIA continue to the present day.

We draw in this paper on the work of Antonio Gramsci who attempted to explain capitalist dominance, and who is credited with introducing the concept of hegemony in the early part of the $20^{\text {th }}$ Century (see section 4), and whose ideas have been updated in line with more recent theory to provide a neo-Gramscian perspective. Thus our aim in this paper is to test the hypothesis that 'passive revolution' (defined in section 4) is used as a strategy to maintain conceptual uncertainty, thereby strengthening the political nature of the EIA system; the effect of which is to support the neoliberal hegemony.

In section 2 we introduce EIA to explain its global relevance, to introduce thinking on its effective, and to clarify the scope of the study. Then we introduce the limited literature that has associated EIA practice with neoliberalism in section 3 . This helps to demonstrate the need for undertaking this research. We follow this with an explanation of neo-Gramscian perspectives (section 4); this serves to provide the theoretical context for our investigation. Section 5 introduces the methods, along 
with a specific hypothesis to act as the basis for investigating narratives of change. Section 6 provides five narratives of change to support the hypothesis. Conclusions are presented in section 7.

\section{Introduction to EIA and effectiveness}

EIA was first legally mandated in the United States through the National Environmental Policy Act (NEPA) in 1969 (Senate and House of Representatives of the United States of America, 1969) in response to debates about the limits to growth and to the conservation movement (Canter, 1996). As MacKinnon et al. $(2018$, p.1) put it, NEPA "marked the beginning of a vast new enterprise of environmental decision-making, complete with regulatory requirements, scientific contributions, and participatory processes". EIA is an ex ante decision-support tool, meaning that it is undertaken in advance of a decision being taken, in order to understand and communicate (through public reporting) what the environmental implications would be of a decision to approve any development application that might have significant environmental effects (the process includes a step to determine which projects must be subject to EIA). It is systematic in that a series of steps must be undertaken, with the exact requirements and order of steps determined by the specific legislation in place in any jurisdiction (Glasson et al., 2012). Where EIA is required, evidence-based predictions are made of the future consequences for the environment if the project goes ahead, with mitigation measures being proposed to reduce or remove significant impacts. EIAs are typically paid for by developers, who usually employ professional environmental consultants; the report of this work is considered by decision-makers in conjunction with their consideration of the development application. Crucially, the EIA process presents opportunities for members of the public, and other stakeholders, to engage with the decision process, with the exact opportunities specified in legislation.

EIA is described as "the most widely emulated environmental policy innovation of the twentieth century" (Karkkainen, 2007, p.45). This global spread can be traced to the Rio Declaration on Environment and Development (signed by over 170 countries) which specifies EIA (in Principle 17) as the tool to be used for projects with potentially significant impacts (United Nations Conference on Environment and Development, 1992). Morgan (2012) subsequently found that EIA had expanded around the world to the point where by 2011 it was mandated in all countries except North Korea and South Sudan. More recently, Yang (2019) cites EIA legislation in both of these countries, and so we can conclude that EIA is now universally required in all countries. Yang $(2019$, p.569) further suggests that "the EIA norm has also become a general principle of law, a part of public international environmental law". 
This has led to considerable debate about the 'effectiveness' of EIA practice (see, for example, Sadler, 1996; Lawrence, 1997; Cashmore et al., 2004; Morgan, 2006; Elling, 2009; Rozema and Bond, 2015). This debate is complicated by the fact that effectiveness is a plural concept and can be framed in many different ways (Bond and Morrison-Saunders, 2013; Pope et al., 2018). At a basic level, Sadler (1996) highlighted the notions of procedural effectiveness (the extent to which an EIA process correctly follows the mandated steps), transactive effectiveness (the extent to which the EIA delivers value for money); and substantive effectiveness (the extent to which EIA delivers its stated goals).

In investigating our aim (that politicising EIA supports neoliberalism), we need to be clear about what exactly we mean by 'EIA' for the purposes of this paper. Sadler (1996), in the International Effectiveness Study on EIA, alluded to different levels at which EIA effectiveness could be evaluated. These levels were further clarified by Morrison-Saunders and Arts (2004) as:

1) meta level - corresponding to the EIA concept and practice globally, examining whether it is a worthwhile process and asking the question: "does EIA work?" (Morrison-Saunders and Arts, 2004, p.6);

2) macro level - corresponding to the EIA system in any given jurisdiction, examining the influence of the process on, inter alia, decision-making and its efficiency; and

3) micro level - corresponding to individual project case studies and relating to specific steps within the process. "A key question is: was the project and the impacted environment managed in an acceptable way?" (Morrison-Saunders and Arts, 2004, p.6).

Our focus for the purposes of this paper is on EIA as a globally implemented concept, i.e. the meta level, as being the most appropriate level at which to investigate the neoliberal hegemony, which is global in scale. It is important to emphasise, however, that practice occurs at the micro level, where it tends to be constrained by macro level regulations, and capacity among networks of stakeholders and the administrative context operating at this level (Turnpenny et al., 2008). We acknowledge frequent evidence of individual cases of good practice, the large number of individuals and organisations responsible for that good practice, and the tremendous variation that exists globally at the micro level (see, for example, Sadler, 1996) and at the macro level (see, for example, Wood, 2003). Meta level practice is less tangible as it refers to a universal concept.

Macro level practice is influenced through the work of organisations like the International Association for Impact Assessment (IAIA), which publishes principles for best practice (International Association for Impact Assessment and Institute of Environmental Assessment, 1999), and organises annual conferences where experiences from practice are shared. This feeds into the practice of 
policy makers for 'lesson drawing' where options in other macro level processes are examined to identify what might be transferred to improve practice (Rose, 1993). In this way, a meta level transfer of practice is facilitated, and a tacit conceptualisation of a system exists (which manifests through academic texts presenting generic EIA process flowcharts, for example, Canter, 1996; Glasson et al., 2012). Further transfer of practice occurs through the work of international organisations like the United Nations Economic Commission for Europe (UNECE) which prepares conventions and protocols which influence macro level practice (see, for example, United Nations Economic Commission for Europe, 1991), and by 94 funding banks signing up to the Equator Principles which include best practice EIA requirements (see Equator Principles Financial Institutions (EPFIs), 2013).

\section{EIA and neoliberalism in the literature}

Literature discussing the relationship between EIA and neoliberal economics is sparse, and searches of Scopus and Google Scholar databases using the search terms "neoliberal" AND/OR "capitalism" AND "environmental assessment" OR "environmental impact assessment" found only three sources relevant to the meta level; one each from Western Australia, South Africa, and India. We present the key content of these works relevant to our arguments below.

In Western Australia, Brueckner et al. (2014) examine the risks associated with mining development to environmental, social and economic sustainability. They argue that the social license to operate is neoliberalised by not giving sufficient attention to social and environmental impacts and that this practise is state government sanctioned. In this context, they concur with Michell and McManus (2013, p.437) who argue that "EIA assists development, rather than offering a means by which alternatives can be explored", through a clear bias. In this source, therefore, EIA is considered to have a political agenda to facilitate development, rather than an objective role in supporting accountable decision-making.

In South Africa, Spocter (2017) cites the neoliberal 'Growth Employment and Redistribution (GEAR) macro-economic strategy', 1996, as facilitating privatisation and, specifically, allowing municipalities to sell municipal land for economic gain. Such sales are subject to EIA, but the authors are clear that these focus on the economic gain in the context of the GEAR strategy, and ignore the social inequalities that might result. That is, the use of evidence within EIA is influenced by a neoliberal (GEAR) strategy to further an economic agenda rather than objectively assessing the full range of social, economic and environmental impacts. 
A different example comes from India where Sundar (2014) described a proposed shift in coastal zone management (CZM) from regulation prohibiting development, to management carried out based on scientific EIA studies based on the enactment of the 'CZM Notification'. Sundar (2014, p.366) argues that "key elements of the CZM Notification may be read as consistent with the generally accepted characteristics of neoliberal governance". However, there was a backlash against the proposals from fishworkers' organisations, coastal communities and NGOs on the basis that the new approach would open up "greater space for violation and exploitation", and "the state's partnership with corporate actors weakened its ability to regulate the very actors who were responsible for the violations of the previous notification" (Sundar, 2014, p.365). The inference here was very much that, rather than facilitating objective and scientific decisions, EIA instead would be the tool of choice for providing the flexibility for corporate actors to press through their own agendas; the backlash experienced associated EIA with neoliberalism and acted to prevent its use.

These three examples hint at neoliberal influence on EIA, but could equally be attributed to isolated acts of corruption, or have other explanations. Nevertheless, the explicit links made between neoliberalism and EIA suggest that further research to examine the links between neoliberalism and EIA is warranted. Implicit links between EIA and the core principles of neoliberalism, on the other hand, are very frequent. For example, Bartlett and Kurian (1999, p.415) propose six implicit models to explain "how EIA is understood to work, how much policy significance is attributed to it, and the meaning it has in the politics of the environment"; one of these they refer to as 'symbolic politics', which they explain as meaning that EIA applies the "rhetoric of science" (Bartlett and Kurian, 1999, p.419) purely to legitimise decisions already made. Using this interpretation, EIA can be manipulated to support any goals, including neoliberal goals.

These examples provide some evidence that other researchers have identified associations between EIA practice and neoliberalism. Taken together they merely hint that EIA is used politically to support the neoliberal hegemony. That is, the examples highlight the need for the research.

\section{Neo-Gramscian perspectives}

Antonio Gramsci was the former leader of the Italian communist party, and was imprisoned by the fascist Government of Italy between 1929 and 1935. During his incarceration he pondered the workings of capitalist societies (Cox, 1983), and provided explanation for capitalist dominance in the early twentieth century. Gramsci focused on national class issues, whereas his ideas have since been extended into other areas of research (this contribution being an example), leading to the 
application of the term neo-Gramscian for this wider application (Levy, 2008). It is argued that one of Gramsci's most significant contributions was "the concept of hegemony, referring to the persistence of specific social and economic structures that systematically advantage certain groups" (Levy and Newell, 2002, p.86). The argument is that hegemony does not come about through control by elites (where Gramsci veered away from Marxist thinking), rather that it depends on implicit consent from coalitions of actors. In this way, it runs counter to arguments that civil society can act as a counterweight, through deliberative democracy, to the pursuit of business and state agendas by powerful actors (Levy et al., 2016). Instead, there is potential for deliberation to be distorted through discourse with powerful actors (Levy et al., 2016). The term given to the specific alliances within the coalitions is the 'historical bloc' which exercises hegemony through state authority, economic dominance and consensual legitimacy of civil society (Levy and Newell, 2005). Gill and Law (1989) clarify that hegemony still involves power being exercised through the state, but that "it was not simply a case of dominance through sanctions, punishments, or inducements; it also involved 'intellectual and moral leadership'" (Gill and Law, 1989, p.476). Thus, power is exercised in more subtle ways and the historical bloc is the link between the state and political society. In the context of EIA, the historical bloc is like to include some elements of the state, political society, industry, developers and even NGOs.

In our introduction we stated that a neoliberal hegemony currently exists. This matters for environmental and sustainability outcomes because research demonstrates that the neoliberal hegemony has shaped environmental governance (Newell, 2008). Newell (2008) further argues that a 'sustainable development historic bloc' has developed to accommodate environmental problems and support the neoliberal hegemony. The function of this bloc is to:

"[D]istance global capitalism from the sources of environmental problems, accommodating some mild criticism of consumerism and globalisation without allowing the 'fatal connection' between the capitalist mode of production and the ecological crisis to be addressed" (Newell, 2008, p.516).

It has been argued that this alignment of sustainable development and neo-liberalism is implicit within the concept of 'ecological modernisation', according to which economic growth and development can be decoupled from environmental harm through eco-efficiency measures, making regulation of industry unnecessary (see, for example, Giorgi and Redclift, 2000; Jamison, 2000; Berger et al., 2001; Owens and Cowell, 2002). A similar argument that the conventional business agenda and the pursuit of sustainability are compatible has also played out in the social and 
environmental accounting literature, despite claims they are in fundamental conflict (Gray and Bebbington, 2000).

Gramsci argued that, despite their dominant position, hegemonies were inherently unstable and maintained this dominance through the strategy of members of the historical bloc, primarily the state. Hegemonic dominance relies on the ongoing support of coalitions of all these actors, and therefore the stability of the hegemony relies on the continuation of a strong enough coalition. Gramsci outlined particular strategies drawn from social conflict literature that could be used either to maintain a hegemonic position or challenge it. The historical bloc will make compromises where it serves to preserve the hegemonic dominance (Davies, 2011); this strategy is termed 'passive revolution' and refers to social, economic and/or political reforms that occur through consent (Matt and Okereke, 2014). Morton (2010) describes passive revolution as accommodation made by dominant groups in order to maintain the support of other members of the historical bloc. On the other hand, other actors (who are not part of the historical bloc) can engage in a 'war of position' (also by consent) to destabilise the historical bloc (Levy and Newell, 2002). Thus passive revolution is conducted by the dominant actors, whilst war of position is a strategy adopted by subordinate groups (Matt and Okereke, 2014).

Passive revolution approaches to maintain the hegemony have included the voluntary adoption by business of, inter alia, corporate environmental management strategies, corporate social reporting, environmental or and/or sustainability reporting. While NGOs and other environmental watchdogs continue to highlight environmental problems, observers argue that they increasingly advocate market solutions and partnerships (Levy and Newell, 2005) including management and reporting approaches. Thus it can be argued that these stakeholders also have become part of the historical bloc and help legitimise the neoliberal hegemony.

The novel hypothesis that we will explore here is that passive revolution is used as a strategy to maintain the political nature of the EIA system, thereby supporting the neoliberal hegemony. Thus, we start to cast light on why (arguably) EIA has become and remains politicised, and to understand the global expansion of EIA as the legislated tool of choice for what is claimed to be evidence-based, accountable decision making.

\section{Methods}

This paper uses a neo-Gramscian perspective based on the concept of the historical bloc, and the associated strategies for supporting or breaking the hegemony. As such, it draws on the analytical 
framework of Levy and Newell (2002) and Levy and Egan (2003) based around: hegemony; historical bloc; and passive revolution.

Given the hypothesis that passive revolution has been used as a strategy to maintain the political nature of the EIA concept (at the meta-level), thereby supporting the neoliberal hegemony, the assumption is that the historical bloc uses passive revolution to accommodate any challenges to the hegemony. To demonstrate that EIA can be used as a vehicle to support this hegemony, we set out to find examples from the literature of passive revolution manifested through changes to the practice of EIA that primarily serve to preserve the historical bloc.

To test our hypothesis, we use narrative enquiry as a method. Squire et al. (2013) distinguish between 'event-centred' and 'experience-centred' narratives, where the former relate to particular past events, and the latter refers to more general stories developing over time and through different media. Here we focus on experience-centred narratives that draw on the historical period over which EIA has been mandated, coincident with the neoliberal hegemony (1970 until present). A narrative-based approach "does not strive to produce any conclusions of certainty, but aims for its findings to be 'well grounded' and 'supportable'"' (Webster and Mertova, 2007, p.4). Specifically, given that passive revolution represents changes accommodated by the historical bloc to maintain the hegemony, we look for narratives of change. This approach has been applied to explore change in many other fields including, inter alia, health behaviour (e.g., Hinyard and Kreuter, 2007), social movements (e.g., Davis, 2012), and environmental change (e.g., Harris, 2009).

As a methodological approach, examining narratives of change is limited in being unable to demonstrate unequivocal causality. Instead, it aims to provide support for a hypothesis that provides an explanation of the paradoxical situation introduced previously - the long-term practice of a decision-support tool with contested effectiveness. The method cannot be applied systematically within a literature review as it explores concepts which do not feature in the EIA literature. Instead it draws on narratives suggested and explored by our own reflections, as EIA experts with cumulative experience exceeding 100 years.

We do not explore 'war of position' (Levy and Newell, 2002) in this paper as it is not needed in order to examine our hypothesis. Our assumption is that, as the neoliberal hegemony persists, no war of position has yet been successful. Albeit that does not explore whether actors have fought a war of position, and failed. 


\section{Passive revolution through EIA}

We provide five narratives which illustrate passive revolution through EIA, starting with shifting goals of the process, and end this section with a tabulated summary of the findings from this analysis.

\subsection{Shifting goals: environmental conservation to sustainable development}

Whilst some authors are clear that the first EIA legislation, the National Environmental Policy Act (Senate and House of Representatives of the United States of America, 1969) was focussed on the human environment (Bina, 2007; Bond et al., 2010), as the legislation spread to other countries the regulations developed often focussed purely on the biophysical environment (Vanclay, 2004). It can therefore be argued that the early development of EIA at the meta level largely had an environmental conservation focus. Now, however, EIA is argued to be fundamentally an instrument for directing decision-making towards sustainable development (Glasson et al., 2012). The shift to a sustainable development focus (and its global expansion) can be traced to the Rio declaration on environment and development (signed by over 170 countries) which specifies (in Principle 17) EIA as the tool to be used for projects with potentially significant impacts (United Nations Conference on Environment and Development, 1992).

O'Riordan and Voisey (1997) argue that the concept of sustainable development has staying power because it is ambiguous and can therefore be interpreted as desired by the currently incumbent political parties. They define four dimensions of sustainable development, and argue that the most powerful is that of "reliable and continuous wealth creation", which they consider to be the mainstay of any mainstream political party (O'Riordan and Voisey, 1997, p.6). Wanner (2015) concurs, arguing that the dominant sustainable development discourse is protected as a means of neoliberalising nature. Sustainable development, as such a plural concept, has fortuitously played into the hands of neoliberals as, on the one hand it gives the impression that it is possible to 'have it all' in the form of economic growth and prosperity coupled with environmental protection (Ashford, 2002) while on the other the argument is made that the three pillars of sustainability (social, economic and environmental) can legitimately be traded off to justify environmentally damaging development.

Trade-offs underpin the 'weak sustainability' discourse that currently dominates (Davidson, 2011). Retief and Morrison-Saunders (2013, p.1) argued that "trade-offs undermine the sustainability potential of impact assessment". It is recognised that assessments invariably lead to trade-off 
choices and, despite arguments that assessments should explicitly identify and avoid significant trade-offs (Gibson, 2013), they remain a consequence of the process (Morrison-Saunders and Pope, 2013). Through presenting information to decision-makers that require trade-offs to be made, EIA plays into the hands of the state especially in the context that EIA approval decision-making typically occurs at a political level and "behind closed doors" (Sadler, 1996, p.16), allowing those with power in the historical bloc to deliver their own agendas legitimised by civil society. For example, Cashmore and Axelsson $(2013$, p.5) highlight in a specific investigation that "power was intimately involved in mediating the influence of the policy E[I]A approach, in both positive (enabling) and negative (constraining) ways".

Thus we contend that the shift to sustainable development as a goal is an example of passive revolution: the historical bloc has facilitated the global spread of EIA, but changed the goals such that environmental conservation can be traded against economic development. At the macro level, this change is evidenced through the expansion in the application of EIA in national jurisdictions as a tool for delivering sustainable development (Glasson et al., 2012). At the micro level, dissatisfaction with the ability of EIA to deliver its goals (as they remain contested) is a pervasive theme in the literature (for example, Noorbakhsh and Ranjan, 1999; Richardson, 2003; Cashmore et al., 2007; Nooteboom, 2007; Morrison-Saunders and Retief, 2012). This maintains conceptual uncertainty given the plural understandings of sustainable development.

\subsection{The use of 'better regulation' to constrain the evolution of EIA}

'Better regulation' is a term coined for the European Union approach to regulatory reform. This reform is a direct response to the proliferation of state regulation that member states were obliged to implement, which was argued to be threatening economic competitiveness (Radaelli, 2007). Whilst different terminology is applied in different parts of the world, better regulation approaches, like neoliberalism, started with the Reagan administration in the USA and the Thatcher administration in the UK and spread across the world (Kirkpatrick and Parker, 2007). Indeed specific tools have been developed, following the EIA model, to ensure better regulation, with Regulatory Impact Assessment being promoted by the OECD, and a specific form of this tool known as Impact Assessment reaching the European Union in 2001 (Wiener, 2007). These tools do not operate at the project level, but copy the EIA approach in terms of a legally or administratively required processbased operation informing decision-making. That is, emerging (draft) legislation is subject to an assessment that aims to predict what the implications of implementing the policy or legislation will 
be. Indeed, research has demonstrated that Impact Assessment practised in the European Union is heavily biased towards investigating economic impacts (Lee and Kirkpatrick, 2006).

Neoliberal responses to the global financial crisis have included acceleration of better regulation policies. Wigger and Buch-Hansen (2013) argue that the advent of better regulation policies are simply a strategy for cushioning the worst effects of free-market competition and therefore aim to maintain the neoliberal hegemony. In turn, at the meta level, EIA legislation has fallen victim to the streamlining effects of better regulation in a number of jurisdictions, for example Canada and the UK (Bond et al., 2014). Practice at the micro level is then affected by macro level changes.

Thus "better" regulation both ensures the dominance of a weak sustainability discourse, thereby maintaining conceptual uncertainty, and also operates to constrain the evolution of EIA where it threatens the neoliberal hegemony. We consider this to be passive revolution because it supports the continuation of EIA as a decision-support tool, subject to ongoing control by the historical bloc of the level of its influence.

\subsection{The procedural nature of mandatory EIA}

The International Association for Impact Assessment (IAIA) conducted an International Effectiveness Study which was published in 1996 (Sadler, 1996). This has provided the basic template for analysing effectiveness as introduced earlier in this paper. Conclusions based on the international study of practice were that procedural effectiveness is generally good at the macro level because of widespread adoption of legal mandates. However, EIA "is judged to be doing a poor job of providing real safeguards in terms of avoiding irreversible change or ensuring development is sustainable" (Sadler, 1996, p.107). This means substantive effectiveness is often poor. These same conclusions, that EIA procedural effectiveness is good, but substantive effectiveness is poor, recur in the literature (Loomis and Dziedzic, 2018).

The National Environmental Policy Act (NEPA) (Senate and House of Representatives of the United States of America, 1969) was a reaction to environmental damage and the culmination of an environmental movement that gained strength in the 1960s. It has substantive provisions enshrined within it, including eliminating damage to the environment and, implicitly, delivering sustainable development (Bond et al., 2010). Yet the Courts in the US considered the substantive requirements too vague to be legally enforceable, in stark contrast to the procedural requirements. Karkkainen (2007, p.47) argues that "Congress and the White House, declined to intervene when agencies went about their business as usual, largely ignoring the substantive policy goals set out in the Act". One of 
the architects of NEPA, Lynton Caldwell, calls this a miscarriage of the intentions of the Act and argues that one of the reasons is the existence of "a commercial economy in which virtually all value is measured in monetary terms" (Caldwell, 1998, p.12). This "emphasis on procedure over substance" (Cole et al., 2004, p.1153), in the absence of specific social or environmental protection embedded in EIA, as we have seen plays into the hands of decision-makers to interpret the evidence to support the outcome they desire (economic benefits).

This is passive revolution as the substantive goals envisaged in legislation have not been implemented as Courts (working as part of the historical bloc) see them as unenforceable, in stark contrast to the procedural goals that are subject to enforcement. Thus, at the macro level, EIA legislation and interpretation of that legislation by national Courts, has developed to favour process rather than substance (Environmental Law Network International (elni), 1997). The procedural nature of EIA then allows decision makers at the micro level to use knowledge gained in an EIA in strategic ways (Hommes et al., 2009), to maintain the neoliberal hegemony.

\subsection{Improving public participation in EIA as a legitimisation strategy}

One area where EIA is considered to have been significantly strengthened over the years relates to the opportunities for public participation in some jurisdictions where the opportunities were initially weak (Morgan, 2012). In Europe, for example, this began with the Espoo Convention that ensured transboundary public participation within EIA (United Nations Economic Commission for Europe, 1991), and was further enhanced through the UNECE Aarhus Convention on access to information, public participation in decision-making and access to justice in environmental matters (United Nations Economic Commission for Europe, 1998). Both Conventions led directly to amendments to the EIA Directive in place in the European Union (European Parliament and the Council of the European Union, 2003), first increasing the geographical reach of participation, and then ensuring greater justice and earlier participation.

This might seem like a challenge to neoliberalism in cases where the economic goals of political elites do not correspond with public views. However, Purcell (2009) argues that neoliberalism suffers from legitimacy problems which must be managed in order to protect the hegemony. He goes on to argue that communicative and collaborative planning, far from challenging neoliberalism, actually provide it with the civil legitimacy that bolsters its existence. This view tallies with that of Leal (2007), who argued that participation initially posed a threat to the neoliberal orthodoxy in developing countries because of grassroots opposition to governing regimes in the 1970 s and 80 s. 
This threat was addressed "by placing emphasis on the techniques of participation, rather than on its meaning, empowerment is thus presented as a de facto conclusion to the initiation of a participatory process ... power-or political - issues are thus translated into technical problems which the dominant development paradigm can easily accommodate" (Leal, 2007, p.544).

At the macro level, improvements in procedural requirements for public participation have been widespread (Morgan, 2012), for example, through implementation of the Aarhus Convention noted previously. This change has led to earlier involvement of the public and broader interpretations of those who have a right to participate. In practice at the micro level, however, Palerm (1999) assert that the improvements fall short of principles for public participation developed based on Habermas' theory of communicative action. Thus, these concessions in terms of greater levels of participation actually focus on procedure and techniques rather than genuine empowerment and, thus, are a classic example of passive revolution used to strengthen the existing positions of political and economic power. There are many authors who advocate for empowering forms of deliberative democracy to become established (e.g., Doelle and Sinclair, 2006; O'Faircheallaigh, 2010; Hartz-Karp and Pope, 2011; Sinclair et al., 2018) in light of these recognised failings with current EIA decisionmaking.

\subsection{Biodiversity offsets as a developer's charter}

In EIA, predicted impacts are supposed to be mitigated to a level where the significance of the impact is acceptable. There is a generally accepted mitigation hierarchy that originally stems from the US Council on Environmental Quality guidelines developed to assist the implementation of the National Environmental Policy Act (1969), the world's first EIA legislation:

1. avoiding the impact altogether by not taking a certain action or parts of an action;

2. minimizing impacts by limiting the degree or magnitude of the action and its implementation;

3. rectifying the impact by repairing, rehabilitating, or restoring the affected environment;

4. reducing or eliminating the impact over time by preservation and maintenance operations during the life of the action; and

5. compensating for the impact by replacing or providing substitute resources or environments.

(Council on Environmental Quality (CEQ) Executive Office of the President, 1978, s. 1508.200)

'Biodiversity offsets' are included as part of the final compensating step in the mitigation hierarchy 
with an aim to counteract biodiversity loss from development with an overall intended outcome of 'no net loss' or even 'net gain' (Rajvanshi et al., 2011; Brownlie et al., 2013). Offsets gained traction when the international Business and Biodiversity Offsets Programme (BBOP) was established in 2004 (ten Kate et al., 2004), highlighting EIA as a facilitating law for triggering offset negotiations. BBOP Business and Biodiversity Offsets Programme (2012, p.14) utilise a "compensation-offset spectrum" that differentiates between mitigation measures that directly offset biodiversity impacts and those that constitute only partial compensation, meaning that they ultimately fall short of no net loss expectations. In a similar approach, the Government of Western Australia (2011) define two types of offset: direct offsets largely in line with the BBOP definition, and indirect offsets which have positive conservation outcomes, but are not specifically related to the impact created by the project; that is, they are a form of trade-off consistent with weak sustainability.

Some recent evaluations of emerging practice at the micro level, however, have suggested that the biodiversity offset approach is a tool of development rather than conservation. Gibbons et al. (2018), for example, investigate offsets in New South Wales and argue that, claims that offsets covered four times the area compared to the area of natural habitat lost were misleading. This is because the offsets involved a combination of the future protection of other natural habitat which was not otherwise at risk, and substituting different types of habitat to those lost. Spash $(2015$, p.541) argues that offsets "use economic logic to legitimise, rather than prevent, ongoing habitat destruction". Narain and Maron (2018) cite the diversion of funds to other conservation programs being used as offsets in India. Maron et al. (2012, p.141) refer to offsets as 'Faustian bargains' based on their examination of the effectiveness of restoration which concludes that "many of the expectations set by current offset policy for ecological restoration remain unsupported by evidence".

Meanwhile, the deployment of offset policies at the macro level can give the impression that any environmental impact can now be contemplated, despite an offsets principle that calls for "limits to what can be offset" (BBOP - Business and Biodiversity Offsets Programme, 2012, p.18). This principle means that not all environmental resources can or should be developed because they are "too special to develop" (McKenney and Wilkinson, 2015, p.5). Middle and Middle (2010, p.322) draw attention to the "possible perception that the proponent is "buying' an approval" when proposing offsets, and we note that current EIA practice in Western Australia frequently includes requirements for proponents to make payments into designated conservation offset funds for every hectare of land disturbed (for example, especially for mining projects in green field areas) with rates of fee payable determined according to the habitat condition of the land to be disturbed. 
Finally, biodiversity offsets are supposed to be a last resort in mitigation after all other mitigation options along the mitigation hierarchy (such as avoidance, minimization, etc.) have been exhausted (BBOP - Business and Biodiversity Offsets Programme, 2012; McKenney and Wilkinson, 2015). In practice however, there is evidence that offsets at the micro level are sometimes considered as the first mitigation option, which has led to claims of being abused as a mitigation option by developers (Clare et al., 2011; Brownlie et al., 2013; Brownlie et al., 2017; de Witt et al., 2019).

Thus the current practical implementation suggests that developers are finding multiple ways to bypass an otherwise stringent policy requirement to protect biodiversity. Moreover, there is evidence that offset negotiations are interpreting no net loss in ways that facilitate development at the expense of conservation. Hence EIA has unwittingly become a vehicle for promoting development by subverting considerations of the significance of biodiversity impacts.

\subsection{Summary of results from analysis of narratives}

Table 1 sets out the key findings associated with the analysis of narratives.

\section{Table 1 Summary of results of narratives analysis}

\begin{tabular}{|l|l|}
\hline \multicolumn{1}{|c|}{ Narrative } & \multicolumn{1}{|c|}{ Example of passive revolution } \\
\hline $\begin{array}{l}\text { Shifting goals: environmental conservation to } \\
\text { sustainable development }\end{array}$ & $\begin{array}{l}\text { A shift towards sustainable development helps } \\
\text { to maintain conceptual uncertainty given the } \\
\text { plural understandings of sustainable } \\
\text { development, thereby potentially providing } \\
\text { greater trade-off space for decision-makers to } \\
\text { pursue neoliberal goals. }\end{array}$ \\
\hline $\begin{array}{l}\text { The use of 'better regulation' to constrain the } \\
\text { evolution of ElA }\end{array}$ & $\begin{array}{l}\text { Better regulation has promoted a weak } \\
\text { sustainability discourse, thereby maintaining } \\
\text { conceptual uncertainty, and also operates to } \\
\text { constrain any evolution of ElA towards delivery } \\
\text { of strong sustainability where it threatens the } \\
\text { neoliberal hegemony. }\end{array}$ \\
\hline The procedural nature of mandatory EIA & $\begin{array}{l}\text { A focus on process has occurred at the expense } \\
\text { of a focus on substance; this leaves decision- } \\
\text { makers free to pursue neoliberal goals, subject } \\
\text { to following the correct procedure. }\end{array}$ \\
\hline $\begin{array}{l}\text { Improving public participation in EIA as a } \\
\text { legitimisation strategy }\end{array}$ & $\begin{array}{l}\text { A focus on procedure and techniques of } \\
\text { engagement has disguised a lack of progress } \\
\text { with genuine empowerment, leaving } \\
\text { neoliberalism as the dominant driver of } \\
\text { decisions. }\end{array}$ \\
\hline
\end{tabular}


Offsets can be (and are being) subverted to deliver development at the expense of biodiversity, rather than being used as a last resort and to demonstrably protect biodiversity and avoid continuing losses. The move towards offsetting has opened up greater spaces for developers to pursue neoliberal goals.

\section{Conclusions}

We have engaged in a meta level analysis of EIA as a concept (after Morrison-Saunders and Arts, 2004) and have found that a neo-Gramscian perspective provides a possible explanation for its popularity as a decision tool in the absence of convincing evidence that it achieves its goal of delivering evidence-based, accountable, decision-making. Furthermore, conceptual uncertainty means that substantive outcomes, including environmental protection, are not agreed goals for the process. This is a significant contribution to thinking on EIA effectiveness as it interprets a number of alleged 'improvements' in a different light. This is important because, if correct, it has far reaching implications for the ability of EIA to achieve its intended goals. It also suggests that strategies to improve the substantive outcomes of EIA need to focus on overcoming the ability of the neoliberal hegemony to subvert changes which are proffered to improve the effectiveness of EIA. We recognise that our perspective is not based on systematic analysis - meta-level analyses based on experiencedcentred narratives rarely can be - and also acknowledge that we have deliberately set out to support, rather than undermine, our hypothesis. Nevertheless, we would suggest that the narrative here is convincing enough to warrant further research and to stimulate reflection by environmental and sustainability practitioners. If further research supports the validity of the neo-Gramscian perspective, then strategies for depoliticising EIA can more easily be designed.

From an environmental conservation viewpoint (where EIA started), Caldwell (1998) argued that civil and property rights are protected by the constitution of the United States, but that the environment enjoys no such constitutional environmental protection. This situation is duplicated in many countries and leads to the current position where many Courts will not implement the substantive requirements of EIA legislation, where they exist, to deliver environmental protection. Whilst the neoliberal hegemony continues, it is difficult to see this situation changing as the historical bloc includes legislators. That is, the neo-Gramscian perspective suggests that, where environmental protection goals exist, they are unlikely to be given constitutional status that might prevent the practice of environmental impacts being traded off against economic gains. 
But alternative ways of delivering substantive goals within the existing hegemony can be developed if they align with the strategy of passive revolution. For example, the Porter Hypothesis, that welldesigned regulation can enhance competitiveness, created a stir when published in 1991 (Ambec et al., 2013). Whilst research has illustrated the hypothesis has bounded validity, the argument is that performance standards (enforcing substantive outcomes) lead to more innovation than technological standards (enforcing process)(Ambec et al., 2013). Translating this in terms of EIA, legislation that regulated substantive outcomes would more likely lead to innovation than would legislation that simply regulated the process - which is what EIA does. It may be possible to play to the neoliberal agenda by finessing arguments in support of environmental protection as a means of enhancing competitiveness of economies; that is, arguments that strong sustainability can be more economically beneficial than weak sustainability in the medium to long term.

Arguments that emphasise economic gain associated with environmental protection (or loss associated with loss of natural capital) are more likely to have purchase with the historical bloc. We see ecosystem services assessment as having potential here. The definitive guide to ecosystem services assessment defined ecosystem services as "the benefits people obtain from ecosystems. These include provisioning services such as food and water; regulating services such as regulation of floods, drought, land degradation, and disease; supporting services such as soil formation and nutrient cycling; and cultural services such as recreational, spiritual, religious and other nonmaterial benefits" (Millennium Ecosystem Assessment, 2003, p.3). There has been considerable interest in valuing ecosystem services (see, for example, Costanza et al., 1997; Bateman et al., 2011) and in embedding ecosystem services assessment into EIA (see, for example, Fothergill et al., 2012; Baker et al., 2013; Karjalainen et al., 2013; Geneletti, 2015). These innovations offer a potential means of improving the substantive effectiveness (in the context of environmental conservation) of EIA in line with neoliberalism.

We have not explored the potential for 'war of position' approaches in this paper, although in Gramscian terms there will be opportunities to influence EIA by anticipating this counter-hegemonic approach. For example, environmental problems (climate change in particular) prove an ongoing threat to the neoliberal hegemony (Levy and Newell, 2002), and could therefore provide the basis for a war of position. Passive revolution might therefore accommodate strategies to adapt EIA to better mitigate climate change impacts. Thus, there may be potential to identify potential war of position opportunities as the basis for depoliticisation strategies.

\section{References}


Ambec, S, M A Cohen, S Elgie and P Lanoie (2013), "The Porter hypothesis at 20: can environmental regulation enhance innovation and competitiveness?", Review of environmental economics and policy, 7(1), pages 2-22.

Ashford, N A (2002), "Government and environmental innovation in Europe and North America", The American Behavioral Scientist, 45(9), pages 1417-1434.

Baker, J, W R Sheate, P Phillips and R Eales (2013), "Ecosystem services in environmental assessment - Help or hindrance?", Environmental Impact Assessment Review, 40(0), pages 3-13.

Bartlett, R V and P A Kurian (1999), "The Theory of Environmental Impact Assessment: Implicit models of policy making", Policy \& Politics, 27(4), pages 415-433.

Bateman, I J, G M Mace, C Fezzi, G Atkinson and K Turner (2011), "Economic analysis for ecosystem service assessments", Environmental and Resource Economics, 48(2), pages 177-218.

BBOP - Business and Biodiversity Offsets Programme (2012), "Standard on Biodiversity Offsets", available at <http://www.foresttrends.org/documents/files/doc 3078.pdf>, last accessed 28th Feb 2018.

Berger, G, A Flynn, F Hines and R G Johns (2001), "Ecological Modernization as a Basis for Environmental Policy: Current Environmental Discourse and Policy and the Implications on Environmental Supply Chain Management", Innovation, 14(1), pages 55-72.

Bina, O (2007), "A critical review of the dominant lines of argumentation on the need for strategic environmental assessment", Environmental Impact Assessment Review, 27(7), pages 585-606.

Bond, A and A Morrison-Saunders (2013), "Chapter 3: Challenges in determining the effectiveness of sustainability assessment", in A Bond, A Morrison-Saunders and R Howitt (editors), Sustainability Assessment: Pluralism, Practice and Progress (Taylor and Francis, London) pages 37-50.

Bond, A, J Pope, A Morrison-Saunders, F Retief and J A E Gunn (2014), "Impact assessment: Eroding benefits through streamlining?", Environmental Impact Assessment Review, 45, pages 46-53.

Bond, A J, C V Viegas, C Coelho de Souza Reinisch Coelho and P M Selig (2010), "Informal knowledge processes: the underpinning for sustainability outcomes in EIA?", Journal of Cleaner Production, 18(1), pages 6-13.

Brenner, N, J Peck and N Theodore (2010), "Variegated neoliberalization: Geographies, modalities, pathways", Global Networks, 10(2), pages 182-222.

Brownlie, S, N King and J Treweek (2013), "Biodiversity tradeoffs and offsets in impact assessment and decision making: Can we stop the loss?", Impact Assessment and Project Appraisal, 31(1), pages 24-33.

Brownlie, S, A von Hase, M Botha, J Manuel, Z Balmforth and N Jenner (2017), "Biodiversity offsets in South Africa-challenges and potential solutions", Impact Assessment and Project Appraisal, 35(3), pages 248-256.

Brueckner, M, A Durey, C Pforr and R Mayes (2014), "The civic virtue of developmentalism: On the mining industry's political licence to develop Western Australia", Impact Assessment and Project Appraisal, 32(4), pages 315-326.

Caldwell, L K (1998), "Implementing Policy Through Procedure: Impact Assessment and The National Environmental Policy Act (NEPA)", in A L Porter and $\mathrm{J} \mathrm{J}$ Fittipaldi (editors), Environmental Methods Review: Retooling Impact Assessment for the New Century (U.S. Army Environmental Policy Institute 
and International Association for Impact Assessment, Fargo, North Dakota) pages 8-14.

Canter, L W (1996), Environmental Impact Assessment (McGraw-Hill, New York).

Cashmore, M and A Axelsson (2013), "The mediation of environmental assessment's influence: What role for power?", Environmental Impact Assessment Review, 39, pages 5-12.

Cashmore, M, A Bond and D Cobb (2007), "The Contribution of Environmental Assessment to Sustainable Development: Toward a Richer Empirical Understanding", Environmental Management, 40(3), pages 516-530.

Cashmore, M, R Gwilliam, R Morgan, D Cobb and A Bond (2004), "The interminable issue of effectiveness: substantive purposes, outcomes and research challenges in the advancement of environmental impact assessment theory", Impact Assessment and Project Appraisal, 22(4), pages 295-310.

Cashmore, M, T Richardson, T Hilding-Ryedvik and L Emmelin (2010), "Evaluating the effectiveness of impact assessment instruments: Theorising the nature and implications of their political constitution", Environmental Impact Assessment Review, 30(6), pages 371-379.

Clare, S, N Krogman, L Foote and N Lemphers (2011), "Where is the avoidance in the implementation of wetland law and policy?", Wetlands Ecol Mgmt, 19, pages 165-182.

Cole, B L, M Wilhelm, P V Long, J E Fielding, G Kominski and H Morgenstern (2004), "Prospects for health impact assessment in the United States: New and improved environmental impact assessment or something different?", Journal of Health Politics, Policy and Law, 29(6), pages 1153-1186.

Costanza, R, R D'Arge, R De Groot, S Farber, M Grasso, B Hannon, K Limburg, S Naeem, R V O'Neill, J Paruelo, R G Raskin, P Sutton and M Van Den Belt (1997), "The value of the world's ecosystem services and natural capital", Nature, 387(6630), pages 253-260.

Council on Environmental Quality (CEQ) Executive Office of the President (1978), Regulations for implementing the pro-cedural provisions of the National Environmental Policy Act, 40 C.F.R. Parts 1500-1508. (CEQ, Washington D.C.).

Cox, R W (1983), "Gramsci, hegemony and international relations: an essay in method", Millennium, 12(2), pages 162-175.

Davidson, K M (2011), "Reporting Systems for Sustainability: What Are They Measuring?", Social Indicators Research, 100(2), pages 351-365.

Davies, J S (2011), Challenging governance theory: From networks to hegemony (Policy Press).

Davis, J E (2012), Stories of change: Narrative and social movements (SUNY Press).

de Witt, M, J Pope, F Retief, A Bond, A Morrison-Saunders and C Steenkamp (2019), "Biodiversity offsets in EIA: Getting the timing right", Environmental Impact Assessment Review, 75, pages 1-12.

Doelle, M and A J Sinclair (2006), "Time for a new approach to public participation in EA: promoting cooperation and consensus for sustainability", Environmental Impact Assessment Review, 26(2), pages 185-205.

Elling, B (2009), "Rationality and effectiveness: does EIA/SEA treat them as synonyms?", Impact Assessment and Project Appraisal, 27(2), pages 121131. 
Environmental Law Network International (elni), (editor). (1997), International Environmental Impact Assessment. European and Comparative; Law and Practical Experience. (Cameron May, London).

Equator Principles Financial Institutions (EPFIs) (2013), "The equator principles: a financial industry benchmark for determining, assessing and managing environmental and social risk in projects", available at <https://equatorprinciples.com/wp-content/uploads/2017/03/equator principles III.pdf $>$, last accessed 14 December 2018.

European Parliament and the Council of the European Union (2003), "Directive 2003/35/EC of the European Parliament and of the Council of 26 May 2003 providing for public participation in respect of the drawing up of certain plans and programmes relating to the environment and amending with regard to public participation and access to justice Council Directives 85/337/EEC and 96/61/EC", Official Journal of the European Communities, L156, pages 17-24.

Fothergill, J, J King, J Murphy, J Owen, S P Smith, J Spurgeon, J Treweek, O Venn and A White (2012), "Considering Ecosystem Services in EIA", available at <http://www.envirotrain.co.uk/wp-content/uploads/2010/09/PN6-01.23Ecosystem-Services-in-EIA.pdf >, last accessed 17 January 2013.

Geneletti, D (2015), "A Conceptual Approach to Promote the Integration of Ecosystem Services in Strategic Environmental Assessment", Journal of Environmental Assessment Policy and Management, 17(04), pages 1550035.

Gibbons, P, A Macintosh, A L Constable and K Hayashi (2018), "Outcomes from 10 years of biodiversity offsetting", Global Change Biology, 24(2), pages e643-e654.

Gibson, R B (2013), "Avoiding sustainability trade-offs in environmental assessment", Impact Assessment and Project Appraisal, 31(1), pages 2-12.

Gill, S R and D Law (1989), "Global hegemony and the structural power of capital", International Studies Quarterly, 33, pages 475-499.

Giorgi, L and M Redclift (2000), "European environmental research in the social sciences: research into ecological modernization as a 'boundary object"', European Environment, 10, pages 12-23.

Glasson, J, R Therivel and A Chadwick (2012), Introduction to Environmental Impact Assessment (Routledge, London).

Government of Western Australia (2011), "WA Environmental Offsets Policy", available at

<http://www.epa.wa.gov.au/sites/default/files/Policies and Guidance/WAEnv OffsetsPolicy-270911.pdf>, last accessed 11th October 2017.

Gray, R and J Bebbington (2000), "Environmental accounting, managerialism and sustainability: Is the planet safe in the hands of business and accounting?", Advances in environmental accounting \& management, 1, pages 1-44.

Harris, L M (2009), "Contested sustainabilities: Assessing narratives of environmental change in southeastern Turkey", Local Environment, 14(8), pages 699-720.

Hartz-Karp, J and J Pope (2011), "Enhancing the effectiveness of SIA through deliberative democracy", in F Vanclay and A-M Esteves (editors), New Directions in Social Impact Assessment: Conceptual and Methodological Advances (Edward Elgar Publishing Limited, Cheltenham, UK).

Hinyard, L J and M W Kreuter (2007), "Using narrative communication as a tool for health behavior change: a conceptual, theoretical, and empirical overview", Health Education \& Behavior, 34(5), pages 777-792. 
Hommes, S, S J M H Hulscher, J P M Mulder, H S Otter and H T A Bressers (2009), "Role of perceptions and knowledge in the impact assessment for the extension of Mainport Rotterdam", Marine Policy, 33(1), pages 146-155.

International Association for Impact Assessment and Institute of Environmental Assessment (1999), "Principles of Environmental Impact Assessment Best Practice", available at <http://iaia.org/publicdocuments/specialpublications/Principles\%20of\%20IA web.pdf>, last accessed 13 December 2018.

Jamison, A (2000), "On the Ambiguities of Greening", Innovation, 13(3), pages 249264.

Jones, D S (2012), Masters of the universe: Hayek, friedman, and the birth of neoliberal politics (Princeton University Press).

Karjalainen, T P, M Marttunen, S Sarkki and A-M Rytkönen (2013), "Integrating ecosystem services into environmental impact assessment: An analyticdeliberative approach", Environmental Impact Assessment Review, 40(0), pages 54-64.

Karkkainen, B K (2007), "NEPA and the curious evolution of environmental impact assessment in the United States", in J Holder and D McGillivray (editors), Taking Stock of Environmental Assessment: Law, Policy and Practice (Routledge-Cavendish, Abingdon) pages 45-63.

Kirkpatrick, C and D Parker (2007), "Regulatory impact assessment: an overview", in C Kirkpatrick and D Parker (editors), Regulatory Impact Assessment: Towards Better Regulation? (Edward Elgar, Cheltenham) pages 1-16.

Lawrence, D P (1997), "Quality and effectiveness of environmental impact assessments: lessons and insights from ten assessments in Canada", Project appraisal, 12(4), pages 219-232.

Leal, P A (2007), "Participation: the ascendancy of a buzzword in the neo-liberal era", Development in practice, 17(4-5), pages 539-548.

Lee, $\mathrm{N}$ and C Kirkpatrick (2006), "Evidence-based policy-making in Europe: an evaluation of European Commission integrated impact assessments", Impact Assessment and Project Appraisal, 24(1), pages 23-33.

Levy, D L (2008), "Political contestation in global production networks", Academy of Management Review, 33(4), pages 943-963.

Levy, D L and D Egan (2003), "A neo-Gramscian approach to corporate political strategy: Conflict and accommodation in the climate change negotiations", Journal of Management Studies, 40(4), pages 803-829.

Levy, D L and P J Newell (2002), "Business strategy and international environmental governance: Toward a neo-Gramscian synthesis", Global Environmental Politics, 2(4), pages 84-101.

Levy, D L and P J Newell (2005), The business of global environmental governance (MIT press).

Levy, D L, J Reinecke and S Manning (2016), "The Political Dynamics of Sustainable Coffee: Contested Value Regimes and the Transformation of Sustainability", Journal of Management Studies, 53(3), pages 364-401.

Loomis, J J and M Dziedzic (2018), "Evaluating EIA systems' effectiveness: A state of the art", Environmental Impact Assessment Review, 68, pages 29-37.

MacKinnon, A J, P N Duinker and T R Walker (2018), The Application of Science in Environmental Impact Assessment (Routledge, London).

Maron, M, R J Hobbs, A Moilanen, J W Matthews, K Christie, T A Gardner, D A Keith, D B Lindenmayer and C A McAlpine (2012), "Faustian bargains? 
Restoration realities in the context of biodiversity offset policies", Biological Conservation, 155, pages 141-148.

Matt, E and C Okereke (2014), "A neo-Gramscian account of carbon markets: the cases of the European Union Emissions Trading Scheme and the Clean Development Mechanism", in B Stephan and R Lane (editors), The Politics of Carbon Markets (Routledge) pages 127-146.

McKenney, B and J Wilkinson (2015), "Achieving Conservation and Development: 10 Principles for Applying the Mitigation Hierarchy Development, Design Program", available at <http://www.nature.org/ourinitiatives/applying-themitigation-hierarchy.pdf $>$, last accessed 9th Dec 2015.

Michell, G and P McManus (2013), "Engaging Communities for Success: social impact assessment and social licence to operate at Northparkes Mines, NSW", Australian Geographer, 44(4), pages 435-459.

Middle, G and I Middle (2010), "A review of the use of environmental offset as a policy mechanism in the environmental impact assessment process (EIA) in Western Australia", Impact Assessment and Project Appraisal, 28(4), pages 313-322.

Millennium Ecosystem Assessment (2003), "Ecosystems and human well-being: a framework for assessment", available at $<$ https://www.millenniumassessment.org/en/Framework.html>, last accessed 18 January 2018.

Morgan, R K (2006), "Solutions to environmental impact assessment failure require more than common sense", Impact Assessment and Project Appraisal, 24(1), pages 15-16.

Morgan, R K (2012), "Environmental impact assessment: the state of the art", Impact Assessment and Project Appraisal, 30(1), pages 5-14.

Morrison-Saunders, A and J Arts (2004), "Introduction to EIA Follow-up", in A Morrison-Saunders and J Arts (editors), Assessing Impact: Handbook of EIA and SEA Follow-up (Earthscan, London) pages 1-21.

Morrison-Saunders, A and J Pope (2013), "Conceptualising and managing trade-offs in sustainability assessment", Environmental Impact Assessment Review, 38, pages 54-63.

Morrison-Saunders, A and F Retief (2012), "Walking the sustainability assessment talk - Progressing the practice of environmental impact assessment (EIA)", Environmental Impact Assessment Review, 36, pages 34-41.

Morton, A D (2010), "The continuum of passive revolution", Capital \& Class, 34(3), pages 315-342.

Narain, D and M Maron (2018), "Cost shifting and other perverse incentives in biodiversity offsetting in India", Conservation Biology.

Newell, P (2008), "The political economy of global environmental governance", Review of International Studies, 34(3), pages 507-529.

Noorbakhsh, F and S Ranjan (1999), "A model for sustainable development: integrating environmental impact assessment and project planning", Impact Assessment and Project Appraisal, 17(4), pages 283-293.

Nooteboom, S G (2007), "Impact assessment procedures for sustainable development: a complexity theory perspective", Environmental Impact Assessment Review, 27(7), pages 645-665.

O'Faircheallaigh, C (2010), "Public participation and environmental impact assessment: purposes, implications, and lessons for public policy making", Environmental Impact Assessment Review, 30(1), pages 19-27. 
O'Riordan, T and H Voisey (1997), "The political economy of sustainable development", Environmental Politics, 6(1), pages 1-23.

Owens, S and R Cowell (2002), Land and limits: Interpreting sustainability in the planning process (Routledge, London).

Palerm, J R (1999), "Public Participation in Environmental Decision Making: Examining the Aarhus Convention", Journal of Environmental Assessment Policy and Management, 1(2), pages 229-244.

Peck, J (2010), Constructions of Neoliberal Reason (Oxford University Press, Oxford).

Pope, J, A Bond, C Cameron, F Retief and A Morrison-Saunders (2018), "Are current effectiveness criteria fit for purpose? Using a controversial strategic assessment as a test case", Environmental Impact Assessment Review, 70, pages 34-44.

Purcell, M (2009), "Resisting neoliberalization: Communicative planning or counterhegemonic movements?", Planning Theory, 8(2), pages 140-165.

Radaelli, C M (2007), "Whither better regulation for the Lisbon Agenda?", Journal of European Public Policy, 14(2).

Rajvanshi, A, S Brownlie, R Slootweg and R Arora (2011), "Maximizing benefits for biodiversity: The potential of enhancement strategies in impact assessment", Impact Assessment and Project Appraisal, 29(3), pages 181-193.

Retief, F and A Morrison-Saunders (2013), "Editorial", Impact Assessment and Project Appraisal, 31(1), pages 1.

Richardson, T (2003), "Environmental assessment and planning theory: four short stories about power, multiple rationalities and the need for situated ethical judgement", Planning for Sustainable Development - the practice and potential of Environmental Assessment, Reykjavik, Iceland, Nordregio, pages 23-51

Rose, $\mathrm{R}$ (1993), Lesson-drawing in public policy (Chatham, New Jersey).

Rozema, J G and A J Bond (2015), "Framing effectiveness in impact assessment: Discourse accommodation in controversial infrastructure development", Environmental Impact Assessment Review, 50, pages 66-73.

Sadler, B (1996), International Study of the Effectiveness of Environmental Assessment Final Report - Environmental Assessment in a Changing World: Evaluating Practice to Improve Performance. (Minister of Supply and Services Canada, Ottawa) 248.

Senate and House of Representatives of the United States of America (1969), "The National Environmental Policy Act of 1969", available at $<$ http://www.epw.senate.gov/nepa69.pdf>, last accessed 27th November 2013.

Sinclair, A J, M Doelle and R B Gibson (2018), "Implementing next generation assessment: A case example of a global challenge", Environmental Impact Assessment Review, 72, pages 166-176.

Spash, C L (2015), "Bulldozing biodiversity: The economics of offsets and trading-in Nature", Biological Conservation, 192, pages 541-551.

Spocter, M (2017), "Privatisation of municipal golf courses in small towns in the Western Cape, South Africa", South African Geographical Journal, 99(2), pages 113-133.

Squire, C, M Andrews and M Tamboukou (2013), "Introduction: what is narrative research?", in M Andrews, C Squire and M Tamboukou (editors), Doing narrative research (Sage, London) pages 1-26. 
Sundar, A (2014), "From regulation to management and back again: Exploring governance shifts in India's coastal zone", Conservation and Society, 12(4), pages 364-375.

ten Kate, K, J Bishop and R Bayon (2004), "Biodiversity offsets: Views, experience, and the business case", available at <https://www.cbd.int/financial/offsets/goffsets-iucn.pdf>, last accessed 8th August 2018.

Turnpenny, J, M Nilsson, D Russel, A Jordan, J Hertin and B Nykvist (2008), "Why is integrating policy assessment so hard? A comparative analysis of the institutional capacities and constraints.", Journal of Environmental Planning and Management, 51(6), pages 759-775.

United Nations Conference on Environment and Development (1992), Earth Summit '92 (Regency Press, London).

United Nations Economic Commission for Europe (1991), Convention on Environmental Impact Assessment in a Transboundary Context (United Nations Economic Commission for Europe, Geneva) 22.

United Nations Economic Commission for Europe (1998), Convention on access to information, public participation in decision-making and access to justice in environmental matters (United Nations Economic Commission for Europe, Committee on Environmental Policy, Geneva) 28.

Vanclay, F (2004), "The Triple Bottom Line and Impact Assessment: How do TBL, EIA, SIA, SEA and EMS relate to each other?", Journal of Environmental Assessment Policy and Management, 6(3), pages 265-288.

Wanner, T (2015), "The New 'Passive Revolution' of the Green Economy and Growth Discourse: Maintaining the 'Sustainable Development' of Neoliberal Capitalism", New Political Economy, 20(1), pages 21-41.

Webster, L and P Mertova (2007), Using narrative inquiry as a research method: An introduction to using critical event narrative analysis in research on learning and teaching (Routledge, Abingdon).

Wiener, J B (2007), "Better Regulation in Europe", in J Holder and D McGillivray (editors), Taking Stock of Environmental Assessment: Law, Policy and Practice (Routledge-Cavendish, Abingdon) pages 65-130.

Wigger, A and $\mathrm{H}$ Buch-Hansen (2013), "Competition, the Global Crisis, and Alternatives to Neoliberal Capitalism: A Critical Engagement with Anarchism", New Political Science, 35(4), pages 604-626.

Wood, C (2003), Environmental Impact Assessment: A Comparative Review (Prentice Hall, Edinburgh).

Yang, T (2019), "The Emergence of the Environmental Impact Assessment Duty as a Global Legal Norm and General Principle of Law", Hastings Law Journal, 70(2), pages 525-572. 